\title{
Pemanfaatan Lahan Sempit Perkotaan Untuk Kemandirian Pangan Keluarga
}

\author{
Suryani ${ }^{1}$, Reni Nurjasmi ${ }^{1}$, Rini Fitri ${ }^{2}$ \\ ${ }^{1}$ Program Studi Agroteknologi, Fakultas Pertanian, Universitas Respati Indonesia, Jakarta \\ ${ }^{2}$ Program Studi Agroteknologi, Fakultas Pertanian, Universitas Al Muslim, Bireun, Aceh \\ Email: edmaryani@yahoo.co.id
}

\begin{abstract}
Abstrak
Pengelolaan lahan adalah proses perencanaan dan pengambilan keputusan, pengorganisasian, pengarahan dan pengendalian sumber daya manusia, keuangan, fisik dan informasi untuk mencapai tujuan organisasi secara efisien dan efektif dalam pengelolaan lahan. Perubahan penggunaan lahan di perkotaan semakin meningkat seiring dengan pertumbuhan dan perkembangan wilayah perkotaan. Pertumbuhan ekonomi dan populasi serta preferensi masyarakat sebagai pendorong perubahan penggunaan lahan tercermin dalam pola penggunaan lahan di perkotaan. Kawasan perkotaan membutuhkan kebijakan untuk mengendalikan perubahan penggunaan lahan untuk mewujudkan kemandirian pangan keluarga dan pembangunan kota yang berkelanjutan. Praktik pertanian di perkotaan yang berkembang saat ini mengikuti karakteristik zona dan sesuai dengan ketersediaan lahan. Kegiatan pertanian perkotaan terbatas pada sayuran, hortikultura, tanaman hias dan tanaman obat. Tulisan ini bertujuan untuk mendeskripsikan pemanfaatan lahan terbatas perkotaan untuk pertanian dan kemandirian pangan keluarga.
\end{abstract}

Kata Kunci : Keterbatasan Lahan, Pertanian Perkotaan, Pangan, Keluarga

\begin{abstract}
Land management is a process of planning and decision making, organizing, leading and controlling of human, financial, physical and information resource to achieve of organizational goals efficiently and effectively in land managing. Land use changes in urban is increase along with the growth and development of urban areas. Economic and population growth and community preferences as drivers of land use change are reflected in land use patterns in urban areas. Urban region need policies to controlling the land use changes to realize family food independence and sustainable urban development. Agricultural practices in urban areas that are developing at this time follow the characteristics of the zone and in accordance with the availability of land. Urban agricultural activities are limited to vegetables, horticulture, ornamental plants and medicinal plants. This paper aims to describe the utilization of urban limited land for agriculture and family food independence.
\end{abstract}

Keywords : Limited Land, Urban Agriculture, Food, Family

\section{PENDAHULUAN}

Kawasan perkotaan umumnya untuk perumahan dan industry sehingga cenderung dikembangkan bagi menyebabkan terjadinya alih fungsi lahan. pemanfaatan lahan non pertanian, Di satu sisi alih fungsi lahan ini menambah pembanguan diperkotaan terkonsentrasi terbukanya lapangan kerja di sektor non-

http://ejournal.urindo.ac.id/index.php/pertanian

Article History :

Sumbitted 12 Desember 2020, Accepted 30 Desember 2020, Published 31 Desember 2020 
pertanian seperti jasa konstruksi, dan industri, akan tetapi juga menimbulkan dampak negatif yang kurang menguntungkan bagi masyarakat perkotaan yaitu terbatasnya lahan untuk pertanian dan bercocok tanam. Keberadaan pertanian bagi masyarakat perkotaan dapat dijadikan sarana untuk mengoptimalkan pemanfaatan lahan dan sumberdaya alam yang ada di kota dengan menggunakan teknologi tepat guna [1]. Walaupun demikian, pertanian diperkotaan tetap menjadi salah satu pola pemanfaatan lahan terbatas yang akan mempengaruhi bentuk sekaligus keberlanjutan dari suatu kawasan perkotaan. Kondisi ini mendorong pemerintah maupun masyarakat di kawasan perkotaan harus mulai mencoba untuk memenuhi kebutuhan pangan keluarga secara mandiri serta memperbaiki kondisi lingkungan agar tercipta lingkungan yang sehat, berkualitas dan berkelanjutan [2].

Daya dukung lahan menunjukkan kawasan perkotaan sangat berpotensi untuk dikembangkan menjadi pertanian perkotaan, pertanian semusim, dan pertanian tahunan, serta pertanian dengan pemanfaatan lahan terbatas pada pusat kawasan yang sudah padat dan minim sarana pertanian. Potensi pengembangan pertanian di kawasan perkotaan ini terjadi persaingan dengan pengembangan kawasan perumahan yang semakin ekstensif terutama di pinggiran kawasan. Pengembangan kawasan pertanian perkotaan tidak hanya dalam dimensi kegiatan pertanian hortikultura saja tetapi juga kegiatan peternakan dan budidaya tanaman intensif. Pertanian perkotaan merupakan kegiatan pertumbuhan, pengolahan, distribusi pangan dan komoditi melalui budidaya tanaman dan peternakan yang intensif di perkotaan dan daur ulang sumber daya alam dan limbah perkotaan, untuk menghasilkan keanekaragaman hasil panen pertanian dan ternak [3]. Kehadiran pertanian perkotaan ini berdampak positiv bukan hanya dalam memenuhi kebutuhan pangan keluarga, tetapi juga terdapat nilai-nilai praktis yang dapat bermanfaat bagi keberlanjutan ekologi, ekonomi wilayah perkotaan dan nilai estetika bagi kualitas lingkungan hidup. Pertanian kota adalah salah satu komponen kunci pembangunan sistem pangan masyarakat yang berkelanjutan dan jika dirancang secara tepat akan dapat mengentaskan permasalahan kerawanan pangan [4]. Dengan demikian semakin meningkatnya tekanan pada kebutuhan produksi pangan, bertambahnya jumlah masyarakat miskin di kota, pertanian perkotaaan akan menjadi satu alternatif yang sangat penting 
untuk mewujudkan kemandirian pangan keluarga. Oleh sebab itu, wilayah perkotaan sangat potensial untuk dikembangkan kawasan pertanian perkotaan yang berkelanjutan sehingga masyarakat perkotaan mampu memenuhi kebutuhan pangan secara mandiri. Tulisan berikut bertujuan menguraikan pengelolaan pertanian perkotaan berwawasan lingkungan dan berkelanjutan. Tulisan berikut bertujuan menguraikan pendayagunaan lahan terbatas perkotaan untuk pertanian dan kemandirian pangan keluarga.

\section{Pemanfaatan Lahan Terbatas Perkotaan}

Tekanan terhadap lahan merupakan upaya yang dilakukan manusia untuk memenuhi kebutuhan hidup terutama kebutuhan sekunder yaitu perumahan di perkotaan. Penggunaan lahan menyebabkan terjadinya tekanan terhadap lahan [5]. Penggunaan Iahan merupakan setiap bentuk intervensi (campur tangan) manusia terhadap lahan dalam rangka memenuhi kebutuhan hidupnya, baik materil maupun spiritual. Peningkatan jumlah penduduk menyebabkan tekanan populasi sehingga mendorong terjadinya perubahan penggunaan lahan [6]. Perubahan penggunaan lahan adalah proses perubahan dari penggunaan lahan sebelumnya ke penggunaan lain yang bersifat permanen atau sementara maupun untuk tujuan komersial [7]. Salah satu faktor yang mempengaruhi perubahan penggunaan lahan adalah kualitas manusia di perkotaan yang berkaitan dengan umur, kepribadian, pendidikan, dan segala sesuatu yang berhubungan dengan pengambilan keputusan sedangkan kuantitas berkaitan dengan jumlah penduduk di perkotaan.

Perubahan penggunaan lahan di kawasan perkotaan pada kenyataannya tidak dapat dihindari karena keinginan manusia untuk memenuhi kebutuhan tidak terbatas namun sumberdaya lahan yang tersedia semakin terbatas. Perubahan penggunaan lahan yang terjadi sebagian besar merupakan penggunaan lahan pertanian menjadi non pertanian yang disebabkan adanya pengaruh perkembangan kota di dekatnya. Penurunan luas lahan pertanian di wilayah perkotaan perlu mendapat perhatian khusus, mengingat hal ini akan membawa dampak negatif terhadap kehidupan perkotaan. Lahan pekarangan yang sempit dan terbatas di perkotaan sebenarnya masih dapat dimanfaatkan untuk kegiatan budidaya pertanian perkotaan. Pemanfaatan lahan sempit di perkotaan merupakan sebuah kegiatan memodifikasi yang dilakukan oleh masyarakat perkotaan 
untuk memaksimalkan lahan terbatas tersebut.

Keberadaan sumberdaya lahan terbatas dan sumberdaya manusia di perkotaan memberikan peluang untuk dimanfaatkan atau dikembangkan sebagai lahan/ruang pertanian perkotaan intensif dan moderen bagi masyarakat tani perkotaan yang sekaligus mendukung pengembangan ruang terbuka hijau di wilayah perkotaan. Informasi sumberdaya pertanian perkotaan sudah banyak hal ini sebagai dukungan terhadap penyusunan konsep dasar pengembangan pertanian perkotaan berkelanjutan. Informasi ini secara detail dan aktual baik berkenaan mengenai biofisik, penggunaan lahan dan ruang, sosial ekonomi, penerapan teknologi dan kebijakan wilayah, merupakan hal penting untuk merumuskan kebijakan pembangunan yang tepat dan secara khusus pengembangan pertanian perkotaan berkelanjutan.

Potensi pemanfaatan lahan terbatas untuk pengembangan pertanian dengan model atau bentuk pertanian perkotaan di arahkan berbasis ruang dan masyarakat yaitu pertanian organik serta sistem insentif, melalui model-model pertanian spesifik lokasi. Pemanfaatan lahan pekarangan melalui penerapan konsep rumah pangan lestari untuk mendukung ketahanan pangan keluarga
[8]. Adapun pemanfaatan lahan sempit untuk pertanian intensif adalah pemanfaatan/mengoptimalkan lahan terbuka, baik lahan sawah, lahan terlantar atau tegalan dengan inovasi teknologi sebagai kebun komoditas. Selain itu juga terdapat ruang terbuka hijau (RTH) produktif dengan memanfaatkan/mengoptimalkan daya hasil pekarangan pemukiman baik komoditas pangan maupun komoditas non pangan. Selaian pemanfaatan RTH dan lahan terlantar, terdapat juga pemanfaatan atap/bangunannya untuk pertanian kebun, pengembangan komoditas sayuran dan tanaman hias.

\section{Praktik Pertanian Perkotaan}

Praktik pertanian perkotaan merupakan praktik budidaya, pemrosesan, juga distribusi bahan pangan dan terwujudnya kemandirian pangan keluarga, praktik wisata serta edukasi. Pertanian perkotaan dapat diselenggarakan apabila memenuhi syarat-syarat untuk terlaksananya kegiatan pertanian dapat dipenuhi mengingat kondisi lahan yang terbatas. Kontribusi dalam pengelolaan dan penataan ruang diperkotaan dengan mengakomodasi tren yang ada di dalam masyarakat, yaitu pertanian perkotaan [9]. Praktik pertanian perkotaan dapat dilakukan dengan melibatkan pihak swasta maupun pemerintah. Praktik pertanian 
perkotaan ini diharapkan dapat menjadi contoh penanganan kota-kota pertanian yang produktif dan dapat menghidupi warga kotanya terutama pangan untuk keluarganya. Praktik di berbagai negara dapat dijadikan contoh baik bagi penerapan pertanian perkotaan di Indonesia. Beberapa kota di Indonesia sudah mulai menerapkan dan mengembangkan pertanian perkotaan (Fauzi et al 2016) [1].

Beberapa contoh praktik pertanian perkotaan diantaranya; praktik penyelenggaraan pertanian perkotaan di Kawasan Sungai Palu yang dimaksudkan untuk meningkatkan pendapatan masyarakat dengan cara memproduksi

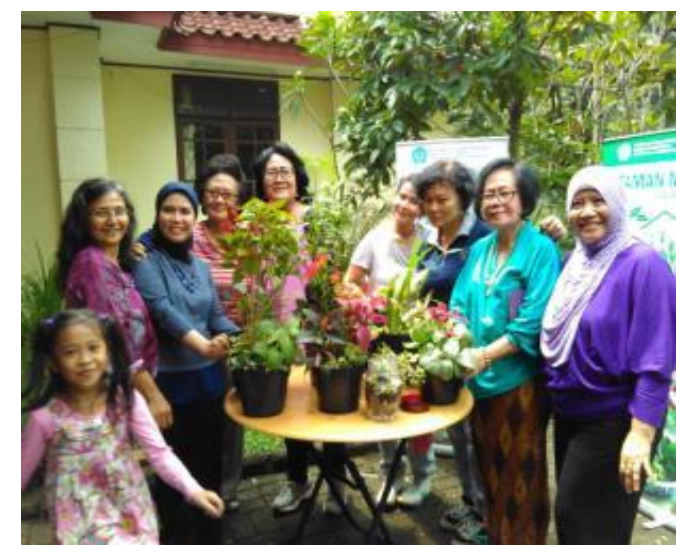

bahan pangan sendiri, untuk dikonsumsi masyarakat Kota Palu dan sekitarnya, juga pendapatan dari usaha lain berbasis pertanian. Selain itu, juga tentunya dilakukan untuk tujuan keindahan kota, rekreasi dan relaksasi bagi masyarakat Kota Palu, termasuk untuk kebutuhan peningkatan tujuan wisata di pusat Kota Palu [9]. Selanjutnya contoh praktik pertanian perkotaan yang lakukan di provinsi DKI Jakarta dengan memanfaatkan lahan terbatas dalam hal ini melibatkan berbagai elemen masyarakat baik anak muda, lansia dan mahasiswa di kampus terutama fakultas pertanian yang di DKI Jakarta hampir semua melaksanakan aktivitas pertanian perkotaan.

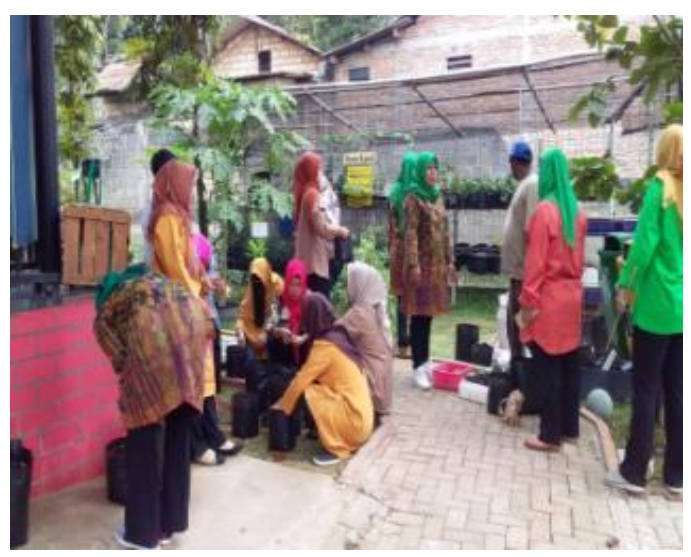

\section{Gambar 1 Praktik pertanian perkotaan dilakukan lansia DKI Jakarta}

(Sumber : Universitas Respati Indonesia Jakarta, 2019)

Praktik pertanian perkotaan di DKI

Jakarta yang dilaksanakan oleh fakultas pertanian dalam hal ini mahasiswa Universitas Respati Indonesia Jakarta melalui penanaman dengan berbagai jenis tanaman pangan, tanaman buah, tanaman obat, dan tanaman hias di berbagai lahan terbatas dan ruang yang tersedia, termasuk di pekarangan, lahan sempit, pinggir jalan dan sungai, atap rumah dan gedung, dinding bangunan, akan 
meningkatkan kualitas lingkungan di Jakarta.
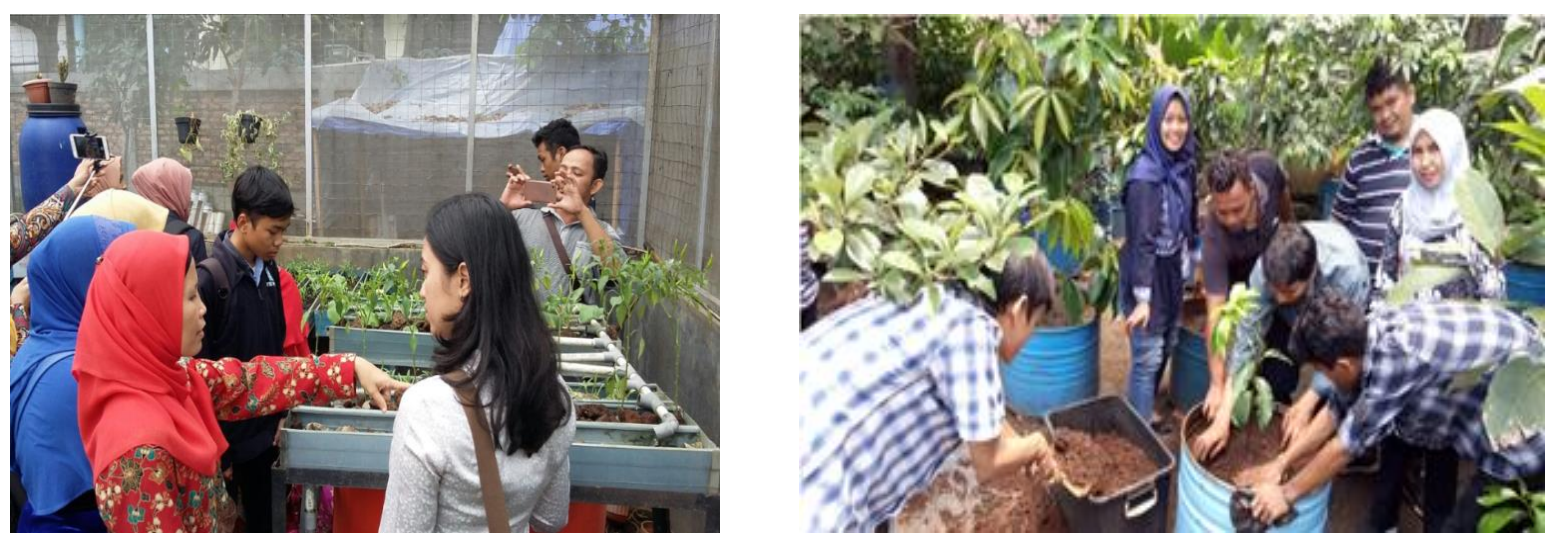

Gambar 2 Praktik pertanian perkotaan dilakukan mahasiswa di DKI Jakarta (Sumber : Universitas Respati Indonesia Jakarta, 2019)

Praktik pertanian perkotaan di DKI Jakarta ini selain memenuhi kemandirian pangan keluarga juga akan berkontribusi terhadap lebih baiknya kualitas udara dan penurunan suhu cuaca panas di Jakarta. Di samping itu, pemanfaatan berbagai ruang terbuka hijau, seperti Ruang Publik

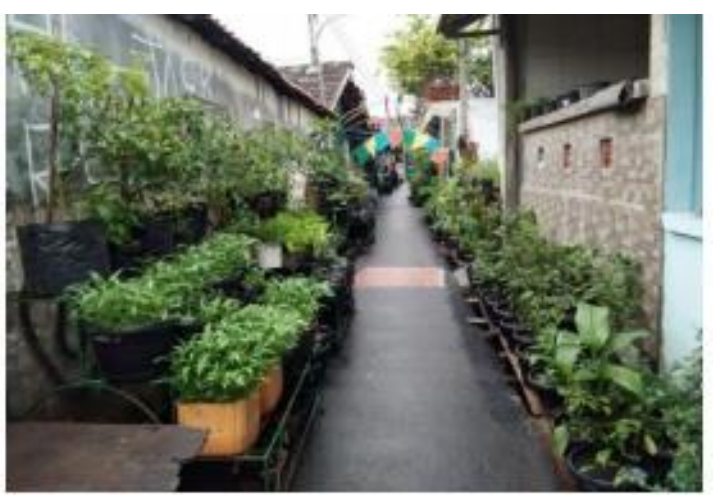

Terpadu Ramah Anak (RPTRA), fasilitas umum, dan fasilitas sosial untuk pertanian akan meningkatan kualitas RTH di Jakarta, yang tidak hanya berfungsi sebagai resapan air, menambah tutupan hijau, ruang bermain, tetapi juga produktifitas pangan di dalamnya [10].

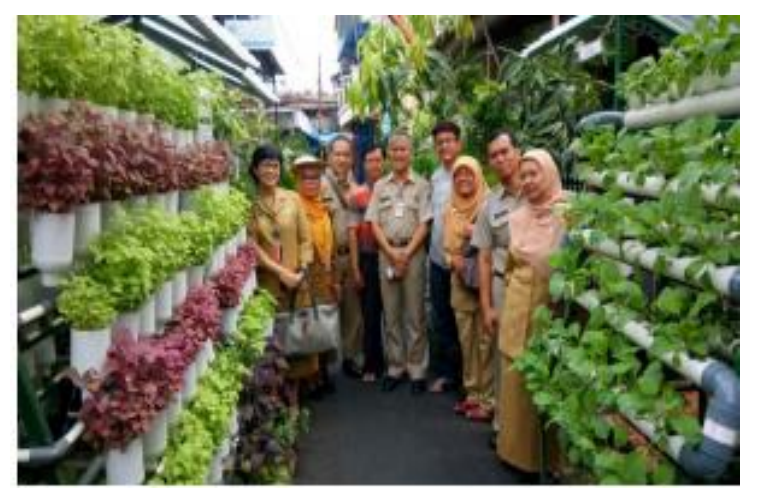

Gambar 3 Contoh Gang Hijau di Menteng Jakarta Pusat dan di Cilincing Jakarta Utara (Sumber: Dinas KPKP, 2017)

Pelaksanaan pertanian perkotaan di DKI Jakarta telah menghasilkan banyak praktik baik yang dilakukan oleh kelompok masyarakat maupun ibu rumah tangga dan menjadi bagian dari sumber pangan keluarga. Misalnya, gang hijau telah dilaksanakan di banyak kelurahan dan hasilnya digunakan untuk memenuhi 
kebutuhan sayuran dan pangan dalam rumah tangga anggota kelompok dan

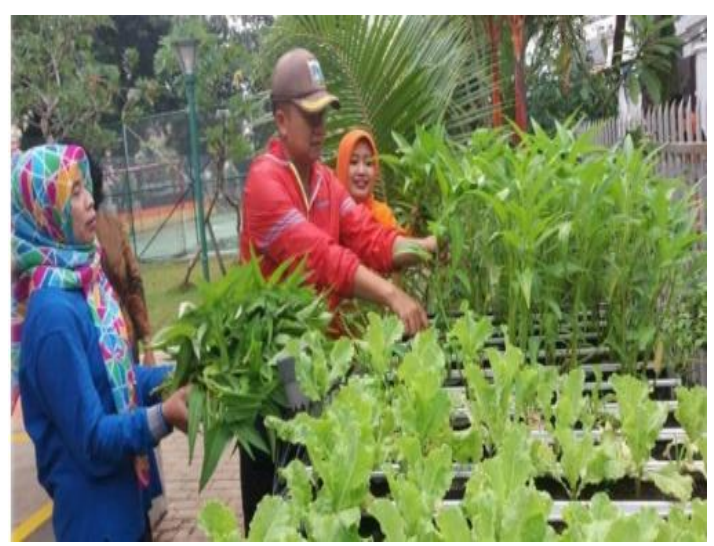

Gambar 4 adalah RPTRA Kenangan di Kecamatan Gambir, Jakarta Pusat.

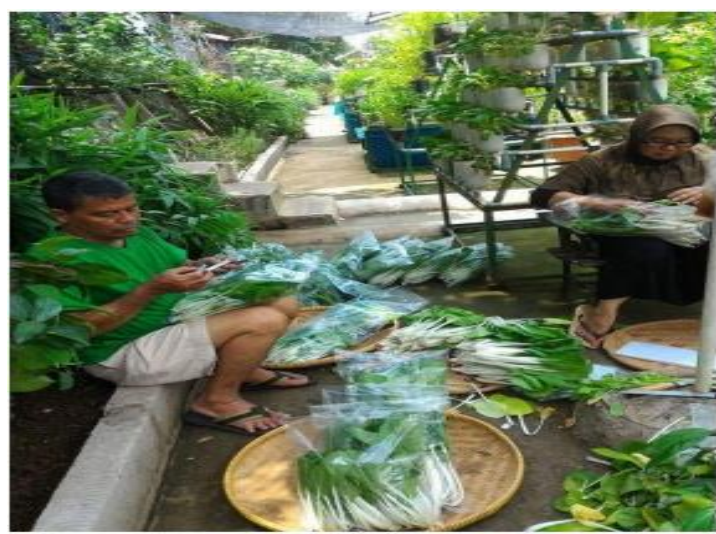

Gambar 4 RPTRA Kenangan, Kec. Gambir, Jakarta Pusat

(Sumber: Dinas KPKP, 2017)

Kebutuhan pangan di perkotaan

Praktik teknologi pertanian perkotaan sederhana seperti hidroponik dalam baskom, polikultur cabai dan sawi, dan budidaya bawang merah dalam pot yang diterapkan kepada Anggota Poktan Bambu Apus Cipayung Jakarta Timur sangat cocok dilakukan karena sebagian besar masyarakat memiliki lahan terbatas. Tanaman yang dibudidayakan pada hidroponik dalam baskom adalah sayuran daun seperti kangkung dan bayam. Teknologi tersebut sangat sederhana dan mudah dilakukan oleh masyarakat serta memerlukan biaya yang sangat murah. Pupuk yang digunakan juga dapat dibuat sendiri menggunakan kulit bawang merah sebagai kompos [11].

Pertanian Perkotaan untuk Kebutuhan Pangan dapat dihasilkan melalui upaya pemanfaatan lahan pekarangan sempit guna memenuhi kebutuhan gizi dan pangan keluarga. Pangan di perkotaan terutama masyarakat miskin perkotaan sangat sulit terpenuhi sehingga akan mengakibatkan rawan pangan dan tidak memenuhi kubutuan gizi yang cukup. Penyebab kerawanan pangan di perkotaan umumnya disebabkan karena masalah ketersediaan pangan dan ketidakmampuan rumah tangga miskin di perkotaan untuk mengakses pangan yang aman, berkualitas dan dalam jumlah yang cukup [12]. Jumlah masyarakat miskin di perkotaan saat ini terus meningkat sehingga memicu masalah ketahanan pangan dan kebutuhan pangan masyarakat miskinnya tidak pernah terpenuhi. Tingginya tingkat urbanisasi dapat menciptakan kelompok masyarakat miskin di perkotaan yang dapat 
mengakibatkan adanya perbedaan akses terhadap pangan setiap rumah tangga dan turut menjadi penyebab timbulnya masalah ketahanan pangan perkotaan [13]. Urbanisasi yang tinggi di perkotaan menjadi masalah terhadap ketersediaan pangan dan akses pangan penduduk perkotaan tidak merata, tingkat kemiskinan yang cenderung meningkat serta menurunnya ketersedian lahan produktif bagi masyarakat perkotaan. Studi tentang pertanian kota saat ini terus berkembang sebagai salah satu solusi berbagai permasalahan terkait ketahanan pangan, banjir, penurunan panas kota, efisiensi energi, kualitas udara, perubahan iklim, hilangnya habitat, dan pencegahan kejahatan [14].

Pertanian perkotaan merupakan salah satu alternatif untuk memenuhi kebutuhan pangan, kebutuhan sehari-hari terutama palawija, pertanakan dan budidaya hortikultura. Produksi bahan makanan sendiri atau dalam kota dapat memperpendek proses distribusi pangan dan dapat mengurangi harga jual sehingga meningkatkan daya beli masyarakat (akses pangan). Ketahanan pangan merupakan kondisi ketika semua orang pada segala waktu baik secara fisik, sosial, dan ekonomi memiliki akses pada pangan yang cukup, aman, dan bergizi untuk pemenuhan kebutuhan konsumsi dan sesuai dengan seleranya (food preferences) demi kehidupan yang aktif dan sehat [15]. Oleh sebab itu, ketahanan pangan masyarakat perkotaan perlu dimulai dari diri masyarakat perkotaan itu sendiri sebagai target sasaran ketahanan pangan. Masyarakat perkotaan juga perlu kesadaran akan kebutuhan pangan yang aman, sehat, dan cukup secara kuantitas untuk kebutuhannya, serta kesadaran bahwa ketersediaan pangan terbatas sehingga memerlukan kontribusi dan peran masyarakat perkotaan agar bijak dalam konsumsi pangan. Kesadaran dan contoh baik untuk berpartisipasi membudidayakan komoditas tanaman pangan seperti budidaya sayur sayuran, palawija, tanaman obat-obatan dan buah-buahan. Tingkat rumah tangga ini juga perlu ditumbuhkan kesadaran dan motivasi bagi masyarakat perkotaan dalam rangka menjamin ketersediaan pangan terutama di tingkat rumah tangganya yang diusahakan pada lahan terbatas.

\section{SIMPULAN}

1. Keberadaan sumberdaya lahan terbatas dan sumberdaya manusia di perkotaan memberikan peluang untuk dimanfaatkan atau dikembangkan sebagai lahan/ruang pertanian perkotaan intensif dan moderen bagi masyarakat tani perkotaan yang sekaligus mendukung pengembangan 
ruang terbuka hijau di wilayah perkotaan.

2. Praktik pertanian perkotaan merupakan praktik budidaya, pemrosesan, juga distribusi bahan pangan dan terwujudnya kemandirian pangan keluarga, praktik wisata serta edukasi. Pertanian perkotaan dapat diselenggarakan apabila memenuhi syarat-syarat untuk terlaksananya kegiatan pertanian dapat dipenuhi mengingat kondisi lahan yang terbatas.

3. Kebutuhan pangan di perkotaan dapat dihasilkan melalui upaya pemanfaatan lahan pekarangan sempit guna memenuhi kebutuhan gizi dan pangan keluarga. Pangan di perkotaan terutama masyarakat miskin perkotaan sangat sulit terpenuhi sehingga akan mengakibatkan rawan pangan dan tidak memenuhi kubutuan gizi yang cukup.

\section{DAFTAR PUSTAKA}

Fauzi, A. R., Ichniarsyah, A. N., \& Agustin, H. 2016. Pertanian Perkotaan: Urgensi, Peranan, dan Praktik Terbaik. Jurnal agroteknologi. 10(1), 49-62.

Noorsya, AO, Kustiwan I. 2013. Potensi Pengembangan Pertanian Perkotaan untuk Mewujudkan Kawasan Perkotaan Bandung yang
Berkelanjutan. Jurnal Perencanaan Wilayah dan Kota. 2(1): 89-99.

Food and Agriculture Organization (FAO). 2008. Urban Agriculture For Sustainable Poverty Alleviation and Food Security. 84p.

Haletky ,N. and O. Taylor. 2006. Urban Agriculture as a Solution to Food Insecurity: West Oakland and People's Grocery. Urban Agriculture in West Oakland.

Mallingreau JP dan Mangunsukoharjo K. 1978. Evaluasi Lahan dan Pendekatan Terpadu Untuk Pembangunan Pedesaan. Yogyakarta (ID): Puspics Bakosurtanal.

Arsyad S. 1989. Konservasi Tanah dan Air. Bogor (ID): Institut Pertanian Bogor.

Muiz A. 2009. Analisis perubahan penggunaan lahan di kabupaten sukabumi. [tesis]. Bogor (ID): Institut Pertanian Bogor.

Rahmah, D.M, Widyasanti, A, Dwiratna, N.P. S. 2016. Pemanfaatan lahan pekarangan dengan menerapkan konsep kawasan rumah pangan lestari. : Jurnal Aplikasi Ipteks untuk Masyarakat. 5(1): 20-21.

Moestopo M, Hamzens, Pingkan S.W.2018. Pengembangan potensi pertanian perkotaan di kawasan sungai palu. 
Jurnal Pengembangan Kota. 6(1):76-

82.

Deputi Gubernur Bidang Tata Ruang dan Lingkungan Hidup. 2018. Desain Besar Pertanian Perkotaan DKI Jakarta Tahun 2018-2030.Jakarta (ID). Pemerintah Provinsi DKI Jakarta.

Nurjasmi, R., S.M. Sholihah, Suryani, L.S. Banu, dan M.A. Wahyuningrum. 2019. Pelatihan Teknologi Budidaya Tanaman Sayuran Di Lahan Sempit Kepada Anggota Poktan Kelurahan Bampu Apus Kecamatan Cipayung Jakarta Timur. Jurnal Pelayanan dan Pengabdian Masyarakat (PAMAS). 3(2): 72-81.

Nughent, R., \& Egal, F. (2000). Urban and periurban agriculture, household food security and nutrition. Paper presented at the electronic conference Urban and Peri-urban Agriculture on the Policy Agenda FAO.
Frayne, B., Battersby-Lennard, J., Fincham, R., \& Haysom, G. (2009). Urban food security in South Africa: case study of Cape Town, Msunduzi and Johannesburg. Development Planning Division Working Paper Series. (15): 14-15. Diakses dari http://www.ruaf.org/ ruaf_bieb/upload/3455.pdf.

Mazeereuw. (2005). Urban Agriculture Report. Region Waterloo. Public Healt.

World Bank. 2013. Urban agriculture findings from four city case studies (Information series No. 18). Washington DC, USA: The World Bank. 